Acta vet. scand. $1976,17,74-82$.

From the Department of Obstetrics and Gynaecology and the Department of Clinical Biochemistry, Veterinary College, Stockholm, Sweden.

\title{
INFLUENCE OF BOARS \\ ON THE RELATIONSHIP BETWEEN FERTILITY AND POST THAWING SPERM QUALITY OF DEEP FROZEN BOAR SPERMATOZOA*
}

By

\author{
K. Larsson and S. Einarsson
}

\begin{abstract}
LARSSON, K. and S. EINARSSON: Influence of boars on the relationship between fertility and post thawing sperm quality of deep frozen boar spermatozoa. Acta vet. scand. 1976, 17, 74-82. - The aim of this investigation was to evaluate the possibility of selecting boars for deep freezing by means of laboratory tests on frozen-thawed spermatozoa.

Thirty-one randomly selected frozen ejaculates from four boars were investigated by a thermoresistance test after thawing in boar seminal plasma and in OLEP. Extracellular ASAT activity was measured in samples from 30 of the ejaculates after thawing in OLEP and in isotonic glucose solution. Twenty of the ejaculates were utilized for fertility tests by artificial insemination of 37 gilts preceding the laboratory investigation.

Three of the boars proved fertile with frozen semen. One of these boars seemed to yield superior fertility to the other two boars. No fertility was obtained with frozen spermatozoa from the fourth boar. Prior to the freezing trial this boar had been used for fresh semen inseminations giving higher pregnancy rates than the average of Swedish A.I.-boars. This boar was therefore considered a case of "low freezability". In the laboratory tests the samples from this boar showed the lowest motility after $3 \mathrm{hrs}$.' storage at $37^{\circ} \mathrm{C}$, the highest relative decrease of motility during the thermoresistance test, the highest release of ASAT after thawing in OLEP and the highest relative release of ASAT. Analyses of variance indicated significant and almost significant variation among boars in relative decrease of motility during the thermoresistance test and in relative release of ASAT.

The results indicate that the boars were the main cause of variation in fertility as well as in outcome of the laboratory tests. These results do not permit a complete evaluation of the relationship between fertility and outcome of the applied laboratory tests. However, the results indicate a possibility of detecting boars producing spermatozoa with low freezability by means of laboratory tests.
\end{abstract}

deep frozen boar spermatozoa; fertility; laboratory tests; freezability.

* This study was supported by grants from Svensk Husdjursskötsel, Hållsta, and the Swedish Council for Forestry and Agricultural Research. 
Differences among boars in fertility of frozen-thawed spermatozoa were recently demonstrated (Larsson \& Einarsson 1976). Varying resistance of the spermatozos from different boars to the freezing-thawing procedure was suggested to be the cause of the variation in fertility. This difference among boars raises a need for laboratory methods to select boars with spermatozoa suitable for deep freezing.

A number of laboratory tests have been utilized to evaluate the effect of freezing methods, diluents and additives. In a previous study on the influence of thawing diluents on post thawing sperm quality (Larsson et al. 1976) the thermoresistance test and the extracellular concentration of aspartate aminotransferase (ASAT, GOT, 2.6.1.1.) were assumed to be good indicators of fertility. However, no information is so far available concerning the relationship between the outcome of these laboratory tests and the fertility of individual boars.

The aim of this investigation was to evaluate the possibility of selecting boars with spermatozoa suitable for deep freezing by the aforementioned tests.

\section{MATERIAL AND METHODS}

Thirty-one randomly selected frozen ejaculates from four boars were investigated with the laboratory tests. Twenty of these 31 ejaculates were utilized for fertility tests by artificial insemination of 37 Swedish cross-bred gilts.

Two Swedish Landrace boars $(172,966)$ and two Swedish Yorkshire boars $(388,1164)$ supplied the semen. The fertility of the boars was previously tested by inseminations of fresh semen or at natural service and found to be good. Before and during the freezing trials their semen quality was examined according to Holst (1949) and Bane (1961) and found to be good.

Freezing and thawing were performed according to the method of Crabo \& Einarsson (1971) as described by Larsson \& Einarsson (1976). Five ejaculates from each of the four boars were utilized in the fertility tests. Boar seminal plasma (A) and OLEP (C) were used as thawing diluents. All gilts were inseminated twice in their second or third spontaneously occurring heat period with an interval of about $16 \mathrm{hrs}$. Each insemination dose contained $6 \times 10^{9}$ spermatozoa added to $70 \mathrm{ml}$ of thawing diluent. Gilts not returning into normal oestrus within 25 days after insemination were slaughtered four weeks after insemination and the number 
of foetuses and corpora lutea (c.l.) were recorded. Gilts returning into normal oestrus within 25 days after insemination were recorded as not pregnant.

In the laboratory tests $1 \times 10^{9}$ spermatozoa from each ejaculate were thawed in $16-18 \mathrm{ml}$ of each of the previously mentioned thawing diluents.

Additionally $1 \times 10^{9}$ spermatozoa from 30 of the ejaculates were thawed in 16-18 ml of isotonic glucose solution for estimation of ASAT release. The preparation of thawing diluents and the thawing procedure were the same as previously described (Larsson et al. 1976).

The thermoresistance test included estimation of motility (percentage of progressively motile spermatozoa) immediately after thawing and after $3 \mathrm{hrs}$.' storage at $37^{\circ} \mathrm{C}$.

Preparation of samples for ASAT release was performed according to Larsson et al. ASAT was determined according to the kinetic method for determination of ASAT in blood as recommended by the Committee on Enzymes of the Scandinavian Society for Clinical Chemistry and Clinical Physiology (1974). Two determinations were made of the enzyme activity from each sample and the mean values were used for calculation of ASAT release per $1 \times 10^{9}$ spermatozoa. The release of ASAT following thawing in isotonic glucose solution was in this study considered an estimate of maximum release. The ratio of ASAT released after thawing in OLEP, to ASAT released after thawing in isotonic glucose solution was calculated for each ejaculate investigated and is in the sequel referred to as "relative release of ASAT". ASAT was not measured in samples thawed in seminal plasma since seminal plasma per se contains ASAT activity which might cause less reliable results.

\section{STATISTICAL ANALYSES}

Conventional statistical methods were used for test of differences (Snedecor 1966). Differences between boars in motility during the thermoresistance test and in ASAT activity after thawing in OLEP were tested by Wilcoxon's rank sum test for unpaired measurements. Variations among boars in relative decrease of motility during the thermoresistance test and in relative release of ASAT were tested by an analysis of variance for groups of unequal size.

The degree of significance is expressed as follows:

$0.05>\mathrm{P}>0.01$ almost significant ${ }^{*}$

$0.01>\mathrm{P}>0.001$ significant ${ }^{*}$ *

$\mathrm{P}<0.001$ highly significant ${ }^{* *}$ 
T a b l e 1. Results of fertility test. Number of ejaculates utilized, number of gilts inseminated, number of gilts pregnant and ratios of foetuses to c.l. in pregnant gilts, as related to boars and thawing diluents.

\begin{tabular}{rccccc}
\hline Boar & $\begin{array}{c}\text { Number of } \\
\text { ejaculates }\end{array}$ & $\begin{array}{c}\text { Thawing } \\
\text { diluent }\end{array}$ & $\begin{array}{c}\text { Number of gilts } \\
\text { inseminated }\end{array}$ & $\begin{array}{c}\text { Number of } \\
\text { gilts pregnant }\end{array}$ & $\begin{array}{c}\text { Ratio of foe- } \\
\text { tuses to c.l. }\end{array}$ \\
\hline 172 & 4 & A & 4 & 2 & 0.48 \\
172 & 5 & G & 5 & 3 & 0.62 \\
388 & 4 & A & 4 & 2 & 0.74 \\
388 & 5 & G & 5 & 4 & 0.76 \\
1164 & 5 & A & 5 & 1 & 0.64 \\
1164 & 4 & G & 4 & 3 & 0.60 \\
966 & 5 & A & 5 & 0 & - \\
966 & 5 & G & 5 & 0 & - \\
\hline
\end{tabular}

\section{RESULTS}

The results of the fertility test are summarized in Table 1. From the table it is evident that boar 388 yielded the highest pregnancy rate and the highest ratio of foetuses to corpora lutea in pregnant gilts. Boars 172 and 1164 yielded lower pregnancy rates and lower ratios of foetuses to c.l. in pregnant gilts than did boar 388. Out of 10 gilts inseminated with spermatozoa from five ejaculates of boar 966 none conceived. It is thus apparent that boar 966 produced spermatozoa of extremely low fertility after freezing and this boar was considered a case of "low freezability".

Ta b l e 2. Results of thermoresistance test after thawing in seminal plasma.

\begin{tabular}{|c|c|c|c|c|c|c|c|}
\hline \multirow[t]{2}{*}{ Boar } & \multirow[t]{2}{*}{$\begin{array}{r}\text { Number of } \\
\text { ejaculates }\end{array}$} & \multicolumn{2}{|c|}{$\begin{array}{l}\text { Initial post thawing } \\
\text { motility }\end{array}$} & \multicolumn{2}{|c|}{$\begin{array}{l}\text { Motility } 3 \mathrm{hrs} \text {. } \\
\text { post thawing }\end{array}$} & \multicolumn{2}{|c|}{$\begin{array}{l}\text { Relative decrease } \\
\text { during storage }\end{array}$} \\
\hline & & mean & range & mean & range & $\overline{\text { mean }}$ & range \\
\hline 172 & 10 & 19.5 & $(10-20)$ & 12.5 & $(5-20)$ & 0.25 & $(0-0.83)$ \\
\hline 388 & 9 & 27.2 & $(10-35)$ & 11.2 & $(1-20)$ & 0.58 & $(0.33-0.90)$ \\
\hline 1164 & 6 & 30.0 & $(25-35)$ & 8.7 & $(0-15)$ & 0.73 & $(0.57-1)$ \\
\hline 966 & 6 & 25.8 & $(10-30)$ & 2.5 & $(0-5)$ & 0.89 & $(0.80-1)$ \\
\hline
\end{tabular}

In the initial post thawing motility the differences between boars were not significant.

Three hrs. post thawing the following significant differences between boars were found: 388-966 $(\mathrm{P}<0.05)^{\star}, 172-966(\mathrm{P}<0.01)^{\star *}$. Analyses of variance indicated significant differences among boars $(\mathrm{P}<0.01)^{* \star}$ in relative decrease of motility during storage. 
T a b l e 3. Results of thermoresistance test after thawing in OLEP.

\begin{tabular}{|c|c|c|c|c|c|c|c|}
\hline \multirow[t]{2}{*}{ Boar } & \multirow[t]{2}{*}{$\begin{array}{r}\text { Number of } \\
\text { ejaculates }\end{array}$} & \multicolumn{2}{|c|}{$\begin{array}{l}\text { Initial post thawing } \\
\text { motility }\end{array}$} & \multicolumn{2}{|c|}{$\begin{array}{l}\text { Motility } 3 \mathrm{hrs} \text {. } \\
\text { post thawing }\end{array}$} & \multicolumn{2}{|c|}{$\begin{array}{l}\text { Relative decrease } \\
\text { during storage }\end{array}$} \\
\hline & & mean & range & mean & range & mean & range \\
\hline 172 & 10 & 29.0 & $(10-35)$ & 11.2 & $(5-20)$ & 0.51 & $(0-0.90)$ \\
\hline 388 & 9 & 35.6 & $(25-40)$ & 15.9 & $(5-30)$ & 0.57 & $(0.14-0.86)$ \\
\hline 1164 & 6 & 33.3 & $(30-40)$ & 5.8 & $(0-10)$ & 0.83 & $(0.71-1)$ \\
\hline 966 & 6 & 30.0 & $(20-40)$ & 1.2 & $(0-5)$ & 0.96 & $(0.83-1)$ \\
\hline
\end{tabular}

The initial post thawing motility did not differ significantly between boars.

Three hrs. post thawing the following significant differences were found between boars: 388-1164 $(\mathrm{P}<0.05)^{\star}$, 388-966 $(\mathrm{P}<0.01)^{\star *}$, $172-966(\mathrm{P}<0.01)^{\star \star}$. Analyses of variance indicated almost significant differences in relative decrease of motility during storage $(\mathrm{P}<0.05)^{*}$.

Table 2 summarizes the results of the thermoresistance test of spermatozoa thawed in seminal plasma, and Table 3 presents the corresponding results for spermatozoa thawed in OLEP. From these tables it is evident that the initial post thawing motility was on the same level for all boars. However, after 3 hrs.' incubation at $37^{\circ} \mathrm{C}$ the motility in all samples from boar 966 was very poor. Significant or almost significant differences in percentages of motile spermatozoa were found between boar 966 and boars 172 and 388 at the end of the thermoresistance test regardless of which thawing diluent was used. Moreover, the percentages of motile spermatozoa in samples from boar 1164 were

T a ble 4. ASAT release of investigated ejaculates after thawing in OLEP and relative release of ASAT after thawing in OLEP.

\begin{tabular}{rccccccc}
\hline Boar & \multicolumn{2}{c}{ ASAT release $\mathrm{mU} / 10^{9}$} & spermatozoa & & \multicolumn{2}{c}{ Relative release of ASAT } \\
\cline { 2 - 3 } \cline { 6 - 7 } & $\begin{array}{c}\text { number } \\
\text { of ejaculates }\end{array}$ & mean & range & & mean & range \\
\hline 172 & 9 & 280 & $(114-950)$ & & 0.28 & $(0.11-0.65)$ \\
388 & 9 & 172 & $(0-398)$ & & 0.23 & $(0-0.59)$ \\
1164 & 6 & 316 & $(0-558)$ & & 0.44 & $(0-0.94)$ \\
966 & 6 & 564 & $(257-1404)$ & & 0.55 & $(0.22-1)$ \\
\hline
\end{tabular}

The release of ASAT after thawing in OLEP was almost significantly higher $(\mathrm{P}<0.05)$ * for boar 966 than for boars 388 and 172; between boars 172 and 388 and boars 1164 and 966 the difference were not significant. Analyses of variance indicated almost significant differences $(\mathrm{P}<0.05)^{*}$ among boars in relative release of ASAT. 
almost significantly lower than the corresponding values for boar 388. The relative decrease in motility during the incubation period varied significantly (after thawing in seminal plasma) or almost significantly (after thawing in OLEP) among boars, indicating that the boars were the main cause of the variation observed.

In Table 4 the extracellular activity of ASAT after thawing is given together with the relative release of ASAT after thawing in OLEP. The table shows that the release of ASAT was lowest in samples from boar 388 and highest in samples from boar 966. The differences between boars 388 and 966 as well as between boars 172 and 966 were almost significant. The relative release varied almost significantly among the boars. The lowest value was obtained for boar 388 and the highest for boar 966. Also these results indicate that the boars were the main cause of the variation observed.

\section{DISCUSSION}

The results of the present fertility test indicate that boar 966 produced spermatozoa of low freezability. When used for fresh semen inseminations prior to the present study this boar yielded higher pregnancy rates than the average of Swedish A.I.-boars. The other boars utilized were all fertile with frozen semen. According to the present results and a previous study utilizing the same boars (Larsson \& Einarsson 1976) the fertility of boar 388 seemed to be superior to that of boars 172 and 1164. Although the fertility data available are limited they indicate larger differences in fertility with frozen semen among boars than between ejaculates within boars.

The laboratory tests as well indicate larger differences between boars than between ejaculates within boars. The poor fertility of boar 966 was connected with poor in vitro survival and with high relative decrease of motility of spermatozoa in the thermoresistance test. These results are in agreement with previous studies (c.f. Einarsson et al. 1972, 1974, Westendorf et al. 1975, Larsson et al. 1976) in which poor in vitro survival due to the influence of thawing diluents has been connected with low fertility of the frozen-thawed spermatozoa. Einarsson \& Viring (1973) showed that spermatozoa with short in vitro survival also disappeared rapidly from the genital tracts of inseminated gilts. This might explain the relationship between poor in vitro sur- 
vival and poor fertility in the present study. In agreement with a previous study (Larsson \& Einarsson 1975) the present results show the limited value of initial post thawing motility as an indicator of sperm quality. However, the relative decrease of motility during the thermoresistance test proved a valuable indicator and thus the initial post thawing motility provided indirect knowledge of the sperm quality. Poor post thawing quality of the spermatozoa from boar 966 was also reflected by high release of ASAT after thawing in OLEP and by high relative release of ASAT. These results are principally in agreement with previous studies (Larsson \& Einarsson 1975, Larsson et al.) in which high release of ASAT (GOT) after thawing was connected with low fertility. For frozen bull semen Pace \& Graham (1970) found a significant correlation between fertility and release of GOT and between fertility and remaining GOT in the spermatozoa.

The material investigated in the present study does not permit analysis of correlation between fertility and outcome of laboratory tests within boars. Until such studies have been performed the relationship between laboratory tests and fertility can not be completely evaluated. At present it does not seem to be possible to select boars of high fertility with frozen semen by means of the available laboratory tests. However, the present results indicate a possibility of detecting boars producing spermatozoa of low freezability. Such an evaluation should include a thermoresistance test with calculation of relative decrease in motility and measurement of ASAT release. To estimate the ASAT release after thawing in OLEP a good comparison will be obtained by measurement of relative release of ASAT as performed in this study.

\section{REFERENCES}

Bane, A.: Acrosomal abnormality associated with sterility in boar. Proc. IVth Int. Congr. Anim. Reprod., The Hague 1961, 4, 810817.

Crabo, B. \& S. Einarsson: Fertility of deep frozen boar spermatozoa. Acta vet. scand. 1971, 12, 125-127.

The Committee on Enzymes of the Scandinavian Society for Clinical Chemistry and Clinical Physiology: Recommended methods for the determination of four enzymes in blood. Scand. J. clin. Lab. Invest. 1974, 33, 291-306.

Einarsson, S. \& S. Viring: Distribution of frozen thawed spermatozoa in the reproductive tract of gilts at different time intervals after insemination. J. Reprod. Fertil. 1973, 32, 117-120. 
Einarsson, S., M. Holtman, O. Soosalu, T. Swensson \& S. Viring: Studies on the fertility and survival of deep frozen boar spermatozoa thawed in four different diluents. Zuchthygiene 1974, 9, 40-45.

Einarsson, S., O. Soosalu, T. Swensson \& S. Viring: On the fertility and survival of deep frozen boar spermatozoa thawed in skim milk. Acta vet. scand. 1972, 13, 446-448.

Holst, S. J.: Sterility in boars. Nord. Vet.-Med. 1949, 1, 87-120.

Larsson, $K$. \& S. Einarsson: Fertility and post-thawing characteristics of deep frozen boar spermatozoa. Andrologia 1975, 7, 25-30.

Larsson, K. \& S. Einarsson: Fertility of deep frozen boar spermatozoa. Influence of thawing diluents and of boars. Acta vet. scand. 1976, 17, 43-62.

Larsson, K., S. Einarsson \& L. Nicander: Influence of thawing diluents on vitality, acrosome morphology, ultrastructure and enzyme release of deep frozen boar spermatozoa. Acta vet. scand. 1976, $17,83-100$.

Pace, M.M.\& E. F. Graham: The release of glutamic oxaloacetic transaminase from bovine spermatozoa as a test method of assessing semen quality and fertility. Biol. Reprod. 1970, 2, 140-146.

Snedecor, G. W.: Statistical Methods. Ames, Iowa 1966, 5th Ed.

Westendorf, P., L. Richter \& H. Treu: Zur Tiefgefrierung von Ebersperma: Labor- und Besamungsergebnisse mit dem Hülsenberger Pailletten-Verfahren. (Deep freezing of boar semen: Laboratory findings and insemination results with the „Hülsenberger Pailletten" technique). Dtsch. tierärztl. Wschr. 1975, 82, 261267.

\section{SAMMANFATTNING}

Galtinflytandet på sambandet mellan fertilitet och spermiekvalitet efter upptining av djupfryst galtsperma.

Ändamålet med föreliggande undersökning var att utvärdera möjligheterna för selektion av galtar för djupfrysning med ledning av laboratorieundersökningar av djupfrysta-upptinade spermier.

Totalt undersöktes 31 ejakulat från 4 galtar med termoresistenstest efter upptining i spermaplasma från galt och i OLEP. Extracellulära ASAT-aktiviteten undersöktes i prover från 30 av ejakulaten efter upptining i OLEP och $i$ isoton glukoslösning. Tjugo av ejakulaten användes för insemination av 37 gyltor $i$ en fertilitetstest, som föregick laboratorieundersökningarna.

Tre av galtarna var fertila med fryst sperma. En av dessa tre galtar gav något bättre dräktighetsresultat än de övriga två. Ingen dräktighet erhölls med fryst sperma från den fjärde galten. Före djupfrysningsförsöken hade denna galt använts i A.I.-verksamhet med färsk sperma och därvid gett bättre dräktighetsresultat än genomsnittet för svenska A.I.-galtar. Denna galt betecknades därför som ett fall av „dålig frysbarhet“. I laboratorieundersökningarna uppvisade 
proverna från denna galt lägre spermiemotilitet än övriga galtar efter 3 timmars förvaring vid $37^{\circ} \mathrm{C}$, den högsta relativa nedgången i motilitet under termoresistenstesten, den högsta frisättningen av ASAT efter upptining i OLEP och den högsta relativa frisättningen av ASAT. Variansanalys påvisade signifikanta och nästan signifikanta skillnader mellan galtar beträffande relativ nedgång i spermiemotilitet under termoresistenstesten och beträffande relativ ASAT frisättning.

Mellangaltsvariationen synes vara den dominerande orsaken både vad gäller skillnader $i$ fertilitet och vad gäller resultaten av laboratorietesterna. De föreliggande resultaten möjliggör inte en fullständig utvärdering av sambandet mellan fertiliteten och utgången av de använda laboratorietesterna. Det synes emellertid vara möjligt att med hjälp av laboratorietester upptäckta galtar som producerar spermier med ,dålig frysbarhet“.

(Received February 17, 1976).

Reprints may be requested from: K. Larsson, the Department of Obstetrics and Gynaecology, Veterinary College, S-104 05 Stockholm 50, Sweden. 